\title{
THE BACK BURNER: EDUCATIONAL EQUITY, RESILIENCE, AND PSYCHOLOGICAL WELL-BEING AS A PREDICTOR ON PROMOTING STUDENTS MENTAL HEALTH
}

\section{Mehboob Ul Hassan ${ }^{1 *}$, Intzar Hussain Butt ${ }^{2}$}

${ }^{1 *}$ Institute of Education and Research, University of the Punjab, Lahore, Punjab, Pakistan; ${ }^{2}$ University of Education,

Township Campus, Lahore, Punjab, Pakistan.

Email: ${ }^{*}$ hassanbhattig@hotmail.com, ${ }^{2}$ ib@ue.edu.pk

Article History: Received on $27^{\text {th }}$ May 2021, Revised on $5^{\text {th }}$ June 2021, Published on $7^{\text {th }}$ June 2021

\begin{abstract}
Purpose of the Study: The purpose of the current research was to determine the effect of equitable education, resilience, and psychological well-being on promoting student's mental health. The researchers eagerly explored everyday situations happening in male elementary schools of district Lahore, focusing on pandemic situations with zeal and zest.
\end{abstract}

Methodology: The researchers structured causal-comparative research focusing positivist paradigm on a sample of randomly selected 980 respondents enrolled in male elementary schools of district Lahore of Punjab-Pakistan. The authors collected the data after administering $\underline{\text { Scott (2006) Educational Equity and school reforms Scale, Prince-Embury }}$ (2013) Resiliency Scales for Children and Adolescents, Ryff's (1989) Psychological Well-beings Scale, and Lukat et al. (2016) Positive Mental Health Scale. After ensuring ethical considerations, the researchers run regression technique, one way; ANOVA and Pearson Product Moment Correlation ( $r$ ) on the participants data.

Main findings: The findings revealed that educational equity effect $81 \%$, resilience $87.10 \%$, and psychological wellbeing affect $66.60 \%$ in promoting students mental health. Educational equity, resilience, and psychological well-being have the same effect on 6th, 7th, and 8th grades students in promoting their mental health. Further a significant strong association between educational equity and mental health $\left(r=.900^{* *}, n=985, p<.05\right)$, resilience and mental health $(r=$ $\left..946^{* *}, n=984, p<.05\right)$ and psychological well-beings and students mental health $\left(r=.815^{* *}, n=985, p<.05\right)$.

Applications of this study: The results of the research will be applicable for headteachers, teachers, and parents to get aware of the worth of equitable education, resilience, and psychological well-being that play an enormous role in promoting students mental health. The debatable constructs of the current research will provide capable stakeholders to know the entire magnitude of mental health that drastically instigate and enhance student's vigour, attentiveness, dependability, intellectual ability, and optimism.

Novelty/originality of this study: It is evident from the literature that less work is conducted inequitable education, resilience, and psychological well-being that play a massive role in promoting students mental health. In the case of Pakistan, the situation is very alarming and the meager because none of the researchers took initiative to framed research on these burning constructs. However, this research will opened new dimensions for the future researchers that will raise their intentions to explore the effect of primary, secondary, higher secondary, and tertiary level students equitable education, resilience, and psychological well-being on their mental health.

Keywords: Educational Equity, Mental Health, Psychological Well-beings, Resilience.

\section{INTRODUCTION}

Institutions are empowering catalytic responsibilities to marginalize their resources, ensuring grassroots realities focusing on a bottom-up approach and evading the technocratic approach that born white colors (Nygreen 2016; Warren, 2014). Organizations are spreading adequate knowledge to produce spirit, strengthen well-being, and overcome students problematic issues. Educational equity, resilience, and psychological well-being are core doctrine that reduces students mental health (Gale, 2011). School is a place where students mental health-related issues are diagnosed (Kessler et al., 2005) and treated through parents collaboration, teachers, headteachers, and community members active support which is associated with students educational opportunities (Colombo, 2006). The parental involvement with diverse socioeconomic status (Hassan \& Akbar, 2020; Plevyak, 2003) and their socio-cultural dynamic is the key factor that affect on students mental health (Martin et al., 2018).

Equity refers to fairness in the need, potential, and achievement of the student. It relates to social justice implications of education with fairness, integrity, and impartiality of its distribution (Jacob \& Holsinger, 2008). Social segregation influences students learning opportunities that include institutional differentiation, selection procedure, and parents choice of school (West, 2006). Educational equity focuses on the fair distribution of resources, access, opportunities, and learning outcomes of students (Maiztegui-Oñate \& Sáñtibanez-Gruber, 2008). Expansion in learning opportunities educational equity is still highly elusive $(\mathrm{OECD}, 2001)$. Equity in education ensures the spreading of fair education applying resources and sources (Centre for Public Education, 2016; Christie, 2010) for poverty-reducing and paves the way to inconsistence inhabitants earnings (Serneels et al., 2017; Vila, 2000) and demands of being equal in position, rank, value, equality, fairness and spreading of education at all level developing learners similar aptitude and behavioural traits rather than equal education for all (UNICEF, 2010; UNESCO, 2017). Equity refers to fairness in need, potential, 
and students educational success. It relates to social justice implications of education concerning fairness, justness, and impartiality of its distribution at all levels (Jacob \& Holsinger, 2008). Educational equity demands change in education policies to close educational disparities, reduce the dropout rate, delinquency, improve economic productivity and increase social stability (Kim et al., 2021; Riordan et al., 2019). Educational policies need to redesign focusing horizontal equity, vertical equity, and equal education opportunity (Maiztegui-Oñate \& Sáñtibanez-Gruber, 2008). Through equity lens expansion in education, the mental health of students, teachers training and pedagogies for diverse population redesign in future focusing educational equity policies, curriculum documents, and education plans (Liou et al., 2017; Rowling, 2009). Evading discrimination is less sufficient for students to attain desired objectives as they have an unequal platform (Crahay, 2000). The pattern of educational equity reshapes the concept of educating, systematizing, and transforming of institutions although they linger tacit (Nygreen, 2016). Applications of educational equity build towering learning among societies depending on teachers high prospect for enhancing students critical thinking and problem-solving abilities (Hamilton et al., 2015; Villegas \& Lucas, 2002).

Resilience recuperates individuals from stress, depression and is a miracle remedy that heals from wounds (Cohen, 2018), an ability that acts as a catalyst for students shelter facing upheavals since eras (Ager et al., 2010) prevent wellbeing and mental health disorders (Awan \& Sitwat, 2014; Hao, 2008; Inter-Agency Standing Committee, 2007; Pardeller et al., 2020), pointed guns towards strengthening learners mental health (Prime et al., 2020), assist in promoting students authoritative uniqueness ability (Poloni et al., 2018) and put attenuating influence focusing anguishing risk experience for learners devastating transformation (Bethell et al., 2014) towards social identities (McAdams \& McLean, 2013). Resilience refers to students improvement (Lin, 2016) towards language acquisition, association, philanthropic modes, emotional impressions, and mental health disorders (Masten, 2014) which are interlinked through ecological interactions (Margain \& Hultman, 2019) provides strapping evidence in Bronfenbrenner's (1997) work. Students story of resilience is embedded with ecological system/proximal processes (Bronfenbrenner \& Morrison, 2006); microsystem inserts considerable and revolutionary influence on students development focusing on family, schools and peers support (Bronfenbrenner, 1997). Ethical concerns of family drastically cultivate students resilience (Hillmann \& Guenther, 2021), reinforce their basis of stability (Walsh, 2016), and enhance coping behaviour towards crises, specifically students with challenging needs (Ager, 2013; Downie et al., 2010). Grandparents actively worked as caregivers and engaged themselves in nurturing students resilience (Chen, 2016). Mesosystem established an association between students Microsystem maximizing their power of defense and threatening in schools surveillance (Bronfenbrenner, 1997) already occurs in mesosystem. Parents, teachers, peers, and ancestors play traditional role in extracting relations between school and family; micro and mesosystems (Hayes et al., 2017) exosystem established far-reaching process of mesosystem consisted of society, neighbourhood, high command officials, and mass media (Bronfenbrenner, 1997). In the early eras of $1977 \mathrm{~s}$, mass media had an indirect influence on students resilience; however, currently, mass media is playing a huge role in students development (Margain \& Hultman, 2019). Association between students resilience and exosystem is auxiliary interlinked among students, microsystem, and mesosystem (Crawford, et al., 2020; Fearnley, 2020). Macrosystem overarches traditions, values, ethnicity, lifestyle, and political system through developing overt and hidden ideologies (Bronfenbrenner, 1977; Panopoulos \& Drossinou-Korea, 2020). Macrosystem indirectly affects parents, teachers, and peers active involvement. Applications of the macrosystem foreground the worth of diverse traditional, political, communal, and cultural aspects that dramatically influence on students resilience towards dependability (Bronfenbrenner, 1977; Grim, 2015; Hayes et al., 2017; Hong et al., 2021).

Well-being is the blend of constructive sentimental situations; happiness, pleasure, joy, and cheers (Deci \& Ryan, 2008), smooth running of life (Huppert, 2009) and is the combination of constructive thoughts towards purposeful performance (Winefield et al., 2012). Psychological well-beings embraced as a key public health object (VanderWeele et al., 2020) that signifies learners finest psychosomatic working and time being experiences focusing his/her hedonism being pleased and eudaimonism stances that place further prominence on being important (Deci \& Ryan, 2008; Khumalo et al., 2012; Ryan \& Deci, 2001). Productive tasks of individuals psychological well-beings revolve around autonomy, environmental mastery, personal development, life intentions, constructive relationships, and self-recognition (Fenwick-Smith et al., 2018; Gao \& McLellan, 2018; Ryff, 2014) that is still becoming an explanatory concept in literature (Helmer \& Hilhorst, 2006; Manyena, 2006; Pantuliano \& Pavanello, 2009). Psychological well-being is strongly associated with bodily fitness, cognitive working pattern, and the significant effect of neurochemical applications on hereditary aspects (Huppert, 2009). Psychological well-being is strongly related to physical and body health (Boehm et al., 2012; Pressman et al., 2019). $\mathrm{Xu}$ and Roberts make their significant contributions in exploring the associations between psychological well-being and students demographic information, health, and social relations. Results revealed that students emotions were playing a significant role in promoting their mental health. Boehm et al. (2011) observed research on a sample of 7,942 participants and found significant association between psychological well-being and risk incidences. Winefiel et al. (2012) framed a qualitative study in Australia to explore self-report measure on psychological well-being and psychological distress on a sample of 1,933 respondents administering standardized instruments from participants. Results of Pearson Product Moment Correlation ( $r$ ) ascertained that psychological well-being negatively correlate with emotional pain and positively correlate with environmental mastery and satisfaction with life.

Mental health meant the promotion of humans actions in constructing fruitful situations for living focusing sound environment that vigorously supports mental health in adopting and maintaining a healthy lifestyle (World Health 
Organization, 2016), individuals emotional, psychological, and social well-being (Keyes, 2002), the approach of happiness towards successful community performance (Westerhof \& Keyes, 2010). Mental health is burning debate of present era (Joshanloo \& Nosratabadi, 2009; Kieling et al., 2011; Weare \& Nind, 2011; Weich et al., 2011; Westrhof et al., 2010) already unbuckled in literature (Anthony \& McLean, 2015; Dix et al., 2012; Fitzpatrick et al., 2013; Hall, 2010) through recommending services of educational institutions and teachers who are playing their massive role in promoting students mental health (Rothi et al., 2008) because students spend the maximum amount of time (Baghian et al., 2019) where students are passing in adulthood (Barnes, 1998) and have the potential to enlarge their cognitive skills (Willingham, 2021). Mental health refers to the individual potential to cope with life stress dynamics (World Health Organization, 2005). Superior mental health allows learners to enjoy a healthy living in school territory (World Health Organization, 2016) in environmental facilitations (O'Reilly et al., 2018) and avoid stress, worry, and unhappiness that hinder students didactic success (Dogra, 2010). Students rate of mental disorders is going to be increased rapidly (Kieling et al., 2011; Kimber et al., 2008). Schools pervasive environment positively influences on students mental health (O'Reilly et al., 2018), while few schools hub of anxiety, tensions, and depressions (Weist \& Murray, 2008) that hinder students educational achievements. Stakeholders interplay "whole school approach" to promote students mental health acknowledging families, staff, local personal, government policies, and in curriculum designing (O'Reilly et al., 2018) in the USA (Collaborative for Academic, Social and Emotional Learning, 2018), KidsMatter in Australia (Department of Health KidsMatter, 2018) and the UK (Social and Emotional Aspects of Learning, 2010) that concrete students mental health and educational success (Public Health England, 2015). Application of the whole-school approach is a challenging task due to lack of adequate funds and staff-support, transparency of uniformity in terminologies, and appropriateness of professionally trained staff for promotion of positive mental health (Rowling, 2009).

\section{Statement of the Problem}

There are strong evidence that globally, 10-20\% of students are suffering from mental health disorders (Kieling et al., 2011), whereas 50\% are ranged in before to 15 years of age (Kessler et al., 2005) that are gradually increasing (State of Education Survey Report, 2017) due to educational equity, resilience and psychological well-beings. Stakeholders are making continuous efforts for perusing equitable education, ensuring resilience and students psychological well-being (Lopez, 2003; Mediratta et al., 2009; Warren \& Mapp, 2011) that put significant effect in promoting students mental health (Fenwick-Smith et al., 2018). It is alarming and needs of the day to put attention on Pakistani stakeholders to take revolutionary measures/conduct researches to resolve the burning dilemma for students. Empirically it is evident that educational equity, resilience and psychological well-being put a significant effect on promoting learners mental health. There exist relative voids in western culture (Ahn, 2011; Puroila \& Estola, 2014) that equity, resilience, and psychological well-beings entirely reduce students mental health but more minor studies structured in non-western culture. Students enrolled in public sector schools are weak in their equitable education, resilience, psychological wellbeings that enhance their mental health due to weak policy implementation (Ahmad et al., 2012) and non-directional educational system (Ahmad et al., 2014). Teachers working in public sector schools depends on student-centered and teacher-centered teaching methods (Hassan \& Akbar, 2020) to remove arduousness (Mahmood, 2013) and weaknesses (van Griethuijsen et al., 2015) focusing on nature of content (Shamsitdinova, 2021) and students cramming (Rehman \& Khan, 2011) that merely enhance students educational achievements. Due to teachers slackness, students less use their cognitive potential in their practical life. On the other hand, public sector students are weak in choosing the realm of equitable education, resilience and psychological well-being. This inefficiently affects on students in obtaining equitable education, resilience, psychological well-being, and destabilized their mental health. Students of public schools are passionately/forcefully allowed to study subjects that buried their educational potential. The current research was an attempt to explore/draw the attention of Pakistani stakeholders to overcome/resolve the impact of educational equity, resilience, and psychological well-beings on promoting students mental health. The researchers have intend to explored the current provision of equitable education focusing on resilience and psychological well-being that work as a catalyst in promoting students mental health. The purpose of the current research was to explore contemporary burning issues happening in male public sector elementary educational institutions of Lahore, Punjab Province of Pakistan.

\section{Research Questions}

Following research questions were addressed in this study:

1. Is there any effect of students educational equity, resilience, and psychological well-being on promoting their mental health?

2. To what extent a significant difference exists occurs among 6th, 7th and 8th-grade students educational equity, resilience, and psychological well-being in promoting their mental health?

3. Is there any degree toward measuring the strength of association among students educational equity, resilience, and psychological well-being towards promoting students mental health?

4. Which is the highest and lowest factor showing its worth in promoting students mental health?

\section{RESEARCH DESIGN AND METHODOLOGY}


The researchers adopted quantitative leading to a positivist paradigm, which provides concrete results on existing conditions (Johnson \& Christensen, 2019; Mertler, 2021), in variables recognition (Boudah, 2019; Zina, 2021) based on shreds of evidences (Fraenkel et al., 2012) focusing apparent facts through applications of accurate statistical techniques (Saldaña, 2021; Fuchs, 2021). This non-experimental research design (Besley, 2019; Houser, 2019) explores the effect of an independent variable(s) on a dependent variable(s) between/among already existed variables (Creswell, 2014; Thomas, 2021). The researchers applied ex post facto design to explore the effect of educational equity, resilience, and psychological well-being which play a significant role in promoting students mental health.

\section{The population of the Study}

The population is whole groups of individuals from required information are collected (Stockemer, 2019), a large group on which results are applied (Fraenkel et al., 2012), and is the group of interest to whom the researchers generalize the results of a study (Bryman, 2016). The population of the current research consisted of 59,001 elementary students, working in 87 male schools of District Lahore (Pakistan Education Statistics, 2018). The researchers selected male students because less possible to access female schools, poor cooperation, and availability of female respondents data.

\section{Sample of the Study}

The sample is a selected part of individuals from the entire population. It is a representative part (Cronk, 2012) that confirm characteristics of the whole population (Fraenkel et al., 2012) involving objects, items, or things from which are being chosen (Stockemer, 2015). The sample helps the researchers in results generalization (Creswell, 2014). In this research, the researchers randomly selected 990 respondents working in public sector male educational institutions.

\section{Instrumentation}

The researchers administered a questionnaire to obtained data from respondents. In causal-comparative research, achievement tests, interview schedules, observational procedure, attitudinal scales, and questionnaires are used as data collection instruments (Fraenkel et al., 2012). A questionnaire timely provides participants insight, entrenched, practical, easily ensures results and planned respondents anonymity (Mertler, 2021; Radhakrishna, 2007; Zouwen, 2000). The researchers administered one questionnaire having 4-parts: Part A: Scott (2006) Educational Equity Scale consists of 6factors; comparably high achievement and other learners outcome 12-items, equitable access and inclusion 15-items, equitable treatment 19-items, equitable opportunity to learn 14-items, equitable resource distribution 10-items and schools accountability consisted of 5-items. Part B: consisted of Prince-Embury, (2013) The Resiliency Scales for Children and Adolescents; RSCA having 64-items categorized in three factors; the sense of mastery 20-items, sense of relatedness, 24-items and emotional reactivity consist of the 20-items mode of 5-point Likert type options rages from never to almost every time. Scale is globally recognized with calculated Cronbach's Alpha Reliability Statistics .90 to .94 and Confirmatory Factor Analysis on data of 9-18 years of age students (Prince-Embury \& Courville, 2008). The initial questionnaire was constructed in English language, then translated into Norwegian language focusing on Brislin (1970) back translation criteria. An independent, resilient Psychologist was having 20 years of enriched experience made a comparison in original and back translation version. The adapted scale was exercised in CFA to assure its resilience. Part C: Ryff's (1989) Psychological Well-being Scale was administered among respondents to gauge their cognitive abilities. Scale comprised 54-items categorized in 6-factor; autonomy 9-items, environmental mastery 9-items, personal growth 9-items, positive relations 9-items, purpose in life 9-items and self-acceptance also consist of 9-items. Scale is standardized and used in different other researches around the globe; in China (Gao \& McLellan, 2018), in South Africa (Henn et al., 2016), in UK (Abbott et al., 2006), and Taiwan (Lee et al., 2019) to gauge participants psychological wellbeing. Furthermore, the scale is applicable to measure and enhance students entire psychological well-being through teachers and spiritual counsellors towards future successful life events (Ryff \& Keyes, 1995). Part D: Lukat et al. (2016) Positive Mental Health Scale consisted of 9-items was administered among respondents to collect data for research purpose. Scale is internationally administered among participants to explore their particular aspect (Trumpf et al., 2009), societal phobia (Trumpf et al., 2010), and mental health (Vriends et al., 2007). The researchers translated questionnaires in the Urdu language from the experts, as students enrolled in elementary schools have poor English language understanding because the medium of instruction has been remaining controversial since independence in Pakistan (Bughio, 2013; Hassan, 2019; Mahmood \& Gondal, 2017; Manan et al., 2021; Taj, 2019). The researchers piloted initial questionnaires on a small sample of the respondents that were not included in the final data collection. The pilot study provides ideas, approaches, and clues to the researchers. It confers warning about instrument failure/success ( $\underline{\text { Smith}}$, 2021; McKenney \& Reeves, 2021). It provides insight into future research hurdle. They sort out potential practical issues faced during the research process (Coates, 2021; McKenney \& Reeves, 2021; Van de Vijver, 2021). After ensuring Cronbach's Alpha Reliability statistics, the researchers collect data from respondents, ensuring ethical considerations; informed consent, volunteer participation, confidentiality, anonymity, integrity, and no physical and psychological harms (Coe et al., 2021; Nguyen, 2021; Smith, 2021; Thomas, 2021; Trevino \& Nelson, 2021). The researchers entered collected data in SPSS for smooth analysis to conquer results. The results/interpretation of parametric statistics has shown a clear picture that to what extent educational equity, resilience, and psychological well-being are putting their significant effect in promoting public sector elementary schools male students mental health.

\section{Data Analysis and Interpretation}


The researchers entered SPSS and applied regression analysis, one-way ANOVA, and Pearson Product Moment Correlation $(r)$ to explore/measure the effect of educational equity, resilience, and psychological well-beings on promoting students mental health. Interpretation of the results is given below:

Table 1: Effect of educational equity, resilience and psychological well-being on students mental health

\begin{tabular}{llcccccccc}
\hline Sr. & \multicolumn{1}{c}{ Model } & $\boldsymbol{F}$ & $\boldsymbol{R}$ & $\boldsymbol{R}^{2}$ & $\boldsymbol{B}$ & $\boldsymbol{S E}$ & $\boldsymbol{\beta}$ & $\boldsymbol{t}$ & $\boldsymbol{p}$ \\
\hline 1 & Mental health (Constant) & 2449.20 & $.969^{\mathrm{a}}$ & .887 & 28.33 & .012 & .97 & 2315.67 & .01 \\
\hline 2 & Educational equity & 4194.32 & $.900^{\mathrm{a}}$ & .810 & .470 & .014 & .90 & 2067.17 & .01 \\
\hline 3 & Resilience & 6645.30 & $.933^{\mathrm{a}}$ & .871 & .362 & .012 & .93 & 2399.16 & .01 \\
\hline 4 & Psychological well-being & 1962.88 & $.816^{\mathrm{a}}$ & .666 & .467 & .020 & .82 & 1392.83 & .01 \\
\hline
\end{tabular}

Note: $R=.883, R^{2}=.782, \beta=.893 ;\left(F(3,987)=4267.50, \mathrm{p}<.05^{\mathrm{a}}\right.$

As established in Table 1, results of multiple regression in case of educational equity with formation of significant equation $(F(3,984)=4194.32, p<.05)$ showing .810 value of $\mathrm{R}^{2}$ with $81.00 \%$ explained variations were observed with standardized regression co-efficient $(\beta=.90)$; resilience $(F(3,984)=6645.30, p<.05)$ possessing .871 value of $R^{2}$ with $87.10 \%$ increased variations were seen with standardized regression co-efficient $(\beta=.93)$ and psychological well-beings $(F(3,984)=1962.88, p<.05)$ opting .666 value of $R^{2}$ with $66.60 \%$ explained variations were reported with standardized regression co-efficient $(\beta=.82)$. Results of independent sample t-test declared that educational equity, $t(985)=2067.17, p<.05$, resilience, $t(985)=2399.16, p<.05$ and psychological beings, $t(985)=1392.83, p<.05$ were significant predictors towards promoting students mental health. Predictions toward enhancing students mental health were equal to $.470+.362+.467$ scores after applying psychological abilities in classroom. It is concludes that students mental health increased 1.229 scores when applying educational equity, resilience and psychological well-beings.

Table 2: Delineating difference among 6th, 7th, and 8th-grade students educational equity, resilience, and psychological well-being in promoting their mental health?

\begin{tabular}{|c|c|c|c|c|c|c|c|}
\hline Sr. & Variables & Levels & $N$ & $M$ & $S D$ & $F$ & $p$ \\
\hline \multirow{3}{*}{1} & \multirow{3}{*}{ Educational equity } & 6th & 354 & 16.14 & 9.47 & \multirow{3}{*}{.055} & \multirow{3}{*}{.967} \\
\hline & & 7 th & 316 & 16.36 & 9.51 & & \\
\hline & & 8 th & 317 & 16.25 & 9.49 & & \\
\hline \multirow{3}{*}{2} & \multirow{3}{*}{ Resilience } & 6th & 354 & 8.333 & 4.59 & \multirow{3}{*}{.055} & \multirow{3}{*}{.846} \\
\hline & & 7th & 316 & 8.253 & 4.61 & & \\
\hline & & 8 th & 317 & 8.372 & 4.59 & & \\
\hline \multirow{3}{*}{3} & \multirow{3}{*}{ Psychological well-being } & 6th & 354 & 17.32 & 9 & \multirow{3}{*}{.037} & \multirow{3}{*}{.673} \\
\hline & & 7 th & 316 & 17.41 & 8.03 & & \\
\hline & & 8 th & 317 & 17.51 & 9.37 & & \\
\hline
\end{tabular}

As delineated in Table 2, results of one way ANOVA declared no significant difference between 6th, 7th and 8th grade students equity, $(F(3,984)=.055, p>.05$, resilience, $(F(3,984)=p>.05)$ and psychological well-being, $(F(3,984)=$ $p>.05)$ in promoting students mental health. It is concluded that educational equity, resilience, and psychological wellbeing have the same influence on 6th, 7th and 8th-grades students in promoting their mental health.

Table 3: Yielding the strength of association among equity, resilience, and psychological well-being towards promoting students mental health

\begin{tabular}{lcccccc}
\hline Variables & $\boldsymbol{M}$ & $\boldsymbol{S D}$ & $\boldsymbol{1}$ & $\mathbf{2}$ & $\mathbf{3}$ & $\mathbf{4}$ \\
\hline 1.Mental health & 27.449 & .498 & - & & \\
\hline 2.Educational equity & 16.132 & 9.478 & $.900^{* *}$ & - & \\
\hline 3.Resilience & 8.320 & 4.590 & $.933^{* *}$ & $.946^{* *}$ & - \\
\hline 4.Psychological well-beings & 17.409 & 8.817 & $-.816^{* *}$ & $.789^{* *}$ & $.815^{* *}$ & - \\
\hline$* *$ Correlation is significant at the .01 level (2-tailed). & & & \\
\hline
\end{tabular}

As established in Table 3, results of Pearson Product Moment Correlation $(r)$ declared significant strong association between educational equity and students mental health $(r=.900 * *, n=985, p<.05)$, significant strong relationship between resilience and mental health $\left(r=.946^{* *}, n=984, p<.05\right)$ and also exist strong significant correlation between psychological well-beings and students mental health $\left(r=.815^{* *}, n=985, p<.05\right)$.

As ascertained in Figure 1, the researchers run descriptive on factors of educational equity, resilience, and psychological well-being to find out maximum and minimum input on promoting students mental health. Interpretation declared that purpose in life was playing maximum input $(M=3.10, S D=1.55)$, whereas equitable opportunities in learning were playing their more negligible role $(M=2.56, S D=1.43)$ in promoting students mental health. 


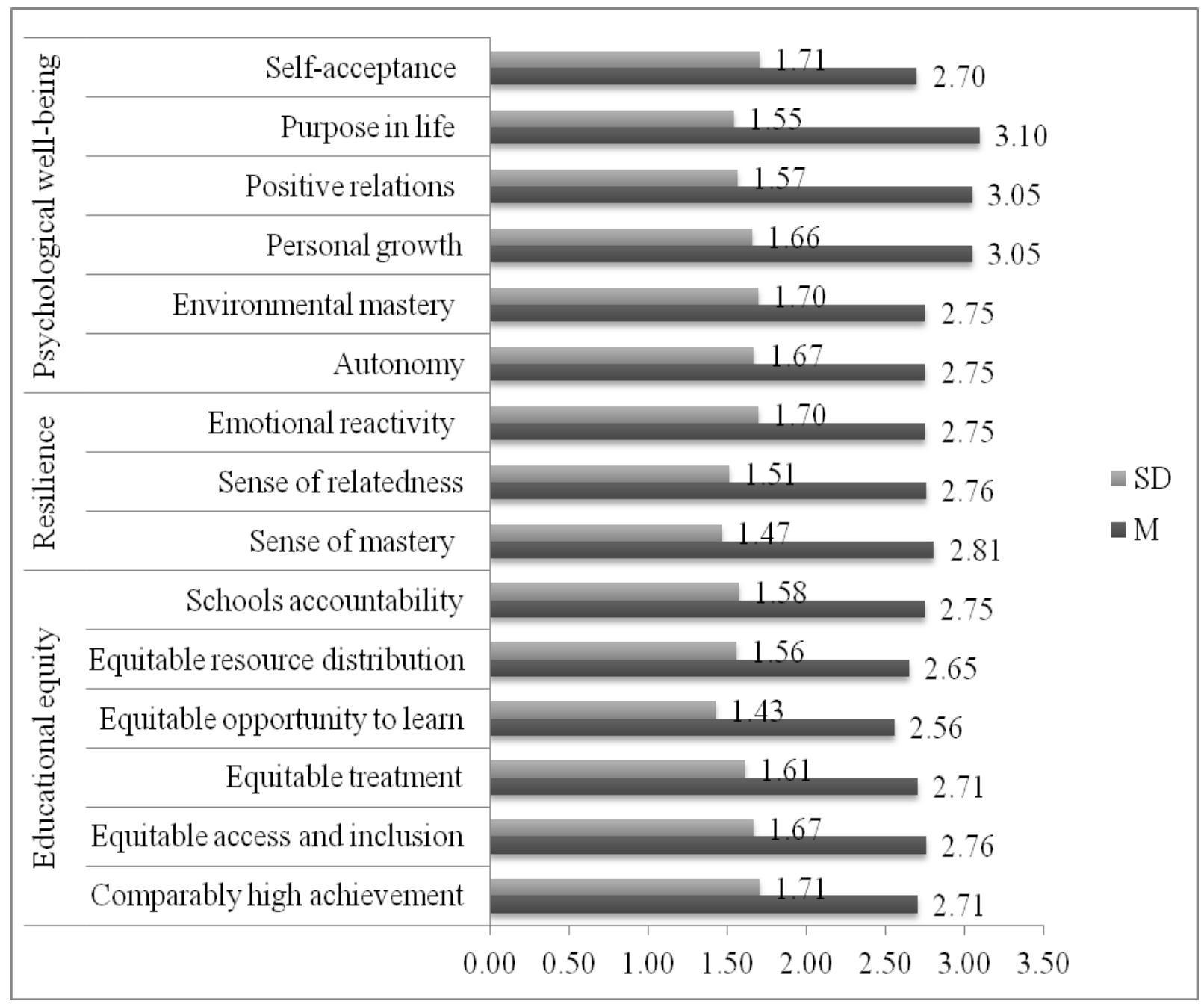

Figure 1: Descriptive statistics on factors of educational equity, resilience, and psychological well-being on promoting students mental health

\section{DISCUSSION}

Educational equity needs to create space, process, and tools to embrace the intricacy of culture, and research centers. Learning opportunities less light on the complexities of students participation, transition, retention, and progression (Willems, 2010). Through equity lens expansion in education, the mental health of students resources, teachers training, and pedagogies for diverse population redesign enhanced focusing policies of educational equity (Gale, 2011; Liou et al., 2017; Rowling, 2009). Educational equity is measured in two dimensions; the extent to which education provided is appropriate and satisfactory, and the educational system provides a guarantee of success for all students (Ainscow, 2016; Takyi et al., 2021; Wilson-Strydom \& Okkolin, 2016). Educational equity is priority concern of policymakers, educational stakeholders, and parents in many settings (Cohen, 2018; Masten \& Narayan, 2012; Ungar, 2012). Results of current research established that educational equity put $81 \%$ effect on promoting students mental health with the formation of significant equation $(F(3,984)=4194.32, p<.05)$ that are congruent with results of research structured by Reyes et al. (2013) whose findings revealed resilience is good predictor on students mental health, and strongly recommends that there is dire need to construct guidelines for students to follow and implement and acquire equitable education having diverse abilities. Moreover, the results of the research conducted by Campbell (2020) established that application of equitable education among students arouse them towards educational success and reduce gender disparities, which also support with findings of doctoral dissertation structured by D'Azevedo (2015), whose findings revealed that equitable education among students enhances students perception towards promoting their school, race and mental health, and also support with the results of the other studies (Foster et al., 2018; Gunin et al., 2021; Nygreen, 2016). Results of the current research strongly congruent with the findings of studies (Gaias et al., 2021; Krass \& Doupnik, 2021; Martin \& Oswin, 2010; Trinidad, 2021) structured in other parts of the world whose findings revealed that provision of equitable education among students continuously enhance students mental health.

Resilience is an active process that is evaluated through individual resistance, reverse back, and development rate (Satici, 2016). Students personality traits; enthusiasm, expectations, wit, ability, abilities, and interests are key indicators that defend from life complicatedness (Bernstein et al., 2017). Resilience founded on usability, sustainability, and purposeful 
societal interconnections with constructive relations (Tomyn \& Weinberg, 2018). Resilience is a significant predictor that promotes students mental health. Results of current research declared that resilience effect $87.10 \%$ on students mental health with formation of significant equation $(F(3,984)=6645.30, p<.05)$. Social scientists Anthony and McLean (2015) make their significant contribution in their research conducted in Australia, whose findings reveal that implementing a key aspect of resilience plan, bouncing back program focusing respondents optimism and self-efficacy is the effective way that promotes students mental health. The findings of the research structured by Bethell et al. (2014) declared that students pampering in schools with a higher rate of resilience conclusively promote students mental health. Resilience is an individual characteristic that is associated with a distinctive way of environmental conditions in an outstanding way (Liu et al., 2017) in which emotions are excel in promoting mental health (Schäfer et al., 2017). Moreover, the results of the current research congruent with the results of other studies conducted in China (Wu et al., 2020), in Spain (Echezarraga et al., 2018; Verdolini et al., 2021) in the UK (Ayed et al., 2019), in Japan (Tamura et al., 2021), in South Africa (Ungar \& Theron, 2020), in USA (PeConga et al., 2020) and in Iran (Samani et al., 2007) whose findings reveal a significant positive relationship between resilience and mental health.

Psychological well-being is a distinct hypothetical variable (Freire et al., 2017) that is openly connected with ones reach, life excellence, and constructive and reasonable evaluation from individuals procedural and holistic viewpoint (PáezGallego et al., 2020). Roots of psychological well-being are linked with persons high self-respect, constructive attitudes, and fewer depression symptoms (Helling \& Chandler, 2021). From an evolutionary viewpoint, there exist abundant proof that psychological well-being is strongly associated with individuals mental health (Loera-Malvaez et al., 2017; Popescu, 2016; Sarfaraz et al., 2019). The results of current research revealed that psychological well-beings affect $66.60 \%$ on promoting students mental health that supports the results of other studies (Foster et al., 2018; Godinic et al., 2020; Otu et al., 2020; Winefield et al., 2012; Hernández-Torrano et al., 2020). Moreover, case of mental health focusing on psychological well-being is significantly associated with non-materialistic benefits; formation of sentimental dealings with peers, fellows, and colleagues and fostering self-respect/self-worth with unique scientific and logical understanding and interpretation of results (Latief \& Retnowati, 2019; Páez-Gallego et al., 2020). Maslow's hierarchy of needs strongly congruent with the parameters of quality of life; safety, love, and belongingness to societal group (Cancino et al., 2016) that are strongly interfering in entire individual existence (Altymurat, 2021; Deptola, 2021; Griffin, 2021; Kaufman, 2021; Luneburg \& Ornstein, 2021; Weiten, 2021). Psychological well-being is well-known for the individual and societal relations and coincidently relates with social and emotional interactions (Latipun et al., 2019; Rosa-Rodríguez et

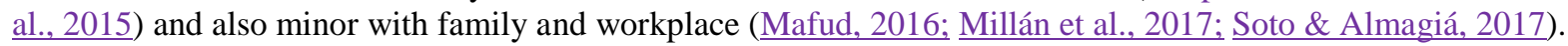

\section{CONCLUSIONS}

Learning opportunities focus on access and inclusion of education and health, which are the fundamental human legal rights of every inhabitant. Students are suffering health issues. Among them, mental health is debatable one. Educational equity, resilience, and psychological well-being centers on promoting learners mental health. Applications of educational equity in societies produce dynamic learners for the delivery of first-class educational equitable aspects. Focusing on the worth of the current scenario, the researchers planned the current research to measure the effect of educational equity, resilience, and psychological well-being on promoting students mental health. The recent research was quantitative, and the researchers applied the causal-comparative design on a sample of randomly selected 3,600 students administering standardized instruments. After ensuring ethical considerations, the researchers collected the data from the participants and entered into SPSS to conquer results. The current research concludes that only $19 \%$ of teachers were weak in providing equitable education, $12.90 \%$ resilient and, $33.40 \%$ were less psychological well-being towards promoting students mental health. The continuous use of pedagogical, technological, and political knowledge get students familiar about their present-day needs. Government maximum investment and utilization stakeholders resources to arouse hidden potential. The slogan of "no cost and low cost" preferred in still applicable in public sector educational institutions for students didactic learning. Teachers training institutions are also playing their significant role in promoting teachers cognitive potential. Availability of computer labs, high-speed internet facilities, vibrant learning environment, ECE, ECD, ICT, STEM education significantly enhance teachers and students hidden abilities. On the other hand, district Lahore is the mother of educational institutions. Indigenous stakeholders move to Lahore for better residence, hospitals, security, shelter, jobs, educational, political, and religious purposes. Resultantly, it all affects on students equity, resilience and, enhanced their psychological well-being that strengthen students mental health. Results of the current results evident that students enrolled in public sector schools of district Lahore can slightly differ in equitable education and familiar with the concept of reasonable schooling, resiliency and psychological well-being.

\section{LIMITATIONS AND RESEARCH FORWARD}

The current research has certain limitations. In this research, the researchers collected the data from the respondents by applying the non-probability sampling technique. Future research scholars may collect the data through probability sampling techniques. The researchers limited the current research on male public sector elementary students while research ground is open for female public and male/female private schools students in the remaining 35-districts of Punjab-Pakistan. The results of this research will open horizons for future/contemporary research scholars to conduct research on primary, secondary, higher secondary, and tertiary level students administering standardized instruments, while self-constructed instruments may be issued after ensuring validation and reliability. 


\section{AUTHOR'S CONTRIBUTION}

Both authors have collectively contributed in this article. We both work wholeheartedly from topic selection to hyperlinked end references.

\section{REFERENCES}

1. Abbott, R. A., Ploubidis, G. B., Huppert, F. A., Kuh, D., Wadsworth, M. E. J., \& Croudace. T. J. (2006). Psychometric evaluation and predictive validity of Ryff's psychological well-being items in a UK birth cohort sample of women. Health and Quality of Life Outcomes, 76(4), 1-16. https://doi.org/10.1186/1477-7525-4-76

2. Ager, A. (2013). Annual research review: Resilience and child well-being-public policy implications, Journal of Child Psychology and Psychiatry, 54(4), 488-500. https://doi.org/10.1111/jcpp.12030

3. Ager, A., Stark, L., Akesson, B., \& Boothby, N. (2010). Defining best practice in care and protection of children in crisis-affected settings: A Delphi study. Child Development, 81, 1271-1286. https://doi.org/10.1111/ j.1467-8624.2010.01467.x

4. Ahmad, I., Rauf, M., Imdadullah, \& Zeb, A. (2012). Implementation gaps in educational policies of Pakistan: Critical analysis of problems and way forward. International Journal of Humanities and Social Science, 2(21), 240-245.

5. Ahmad, I., Rehman, K. U., Ali, A., Khan. I., Khan, F. A. (2014). Critical analysis of the problems of education in Pakistan: Possible solutions. International Journal of Evaluation and Research in Education, 3(2), 79-84. https://doi.org/10.11591/ijere.v3i2.1805

6. Ahn, J. (2011). Review of children's identity construction via narratives. Creative Education, 2(5), 415-417. https://doi.org/10.4236/ce.2011.25060

7. Ainscow, M. (2016). Diversity and equity: A global education challenge. New Zealand Journal of Educational Studies, 51(2), 143-155. https://doi.org/10.1007/s40841-016-0056-X

8. Altymurat, A. (2021). Human behavior in organizations related to Abraham Maslow's hierarchy of needs theory. Interdisciplinary Journal Papier Human Review, 2(1), 12-16. https://doi.org/10.47667/ijphr.v2i1.87

9. Anthony, H., McLean, L. (2015). Promoting mental health at school: Short-term effectiveness of a popular school-based resiliency programme. Advances in School Mental Health Promotion, 8(4), 199-215. https://doi.org/10.1080/1754730X.2015.1065188

10. Awan, S., \& Sitwat, A. (2014). Workplace spirituality, self-esteem, and psychological well-being among mental health professionals. Pakistan Journal of Psychological Research, 29(1) 125-149.

11. Ayed, N., Toner, S., Priebe, S., (2019). Conceptualizing resilience in adult mental health literature: A systematic review and narrative synthesis. Psychology and Psychotherapy: Theory, Research and Practice, 92(3), 299-341. https://doi.org/10.1111/papt.12185

12. Baghian, N., Sari, A. A., Shati, M., Fallahzadeh, H., \& Ahmadi, B. (2019). Evaluation of students mental and social health promotion educational programs: A systematic review. Journal of Education and Health Promotion, 31(8), 258. https://doi.org/10.4103/jehp.jehp_416_19.

13. Barnes, J. (1998). Mental health promotion: A developmental perspective. Psychology, Health \& Medicine, 3(1), 55-69. https://doi.org/10.1080/13548509808400590

14. Bernstein, K., Park, S. Y., \& Nokes, K. M. (2017). Resilience and depressive symptoms among Korean Americans with a history of traumatic life experience. Community Mental Health Journal, 53(7), 793-801. https://doi.org/10.1007/s10597-017-0142-7

15. Besley, T. A. (2019). Assessing the quality of educational research in higher education: International Perspectives. Brill Publishers.

16. Bethell, C. D., Newacheck, P., Hawes, E., \& Halfon, N. (2014). Adverse childhood experiences: assessing the impact on health and school engagement and the mitigating role of resilience. Health Affairs, 33(12), 21062115. https://doi.org/10.1377/hlthaff.2014.0914

17. Boehm, J. K., \& Kubzansky, L. D. (2012). The heart's content: The association between positive psychological well-being and cardiovascular health. Psychological Bulletin, 138(4), 55-91. https://doi.org/10.1037/a0027448

18. Boehm, J. K., Peterson, C., Kivimaki, M., \& Kubzansky, L. (2011). A prospective study of positive psychological well-being and coronary heart disease. Health Psychology, 30, 259-267. https://doi.org/10 $.1037 / \mathrm{a} 0023124$

19. Boudah, D. J. (2019). Conducting educational research:" guide to completing a thesis, dissertation, or action research project". Sage Publications.

20. Brislin, R. W. (1970). Back-translation for cross-cultural research. International Journal of Psychology, 1(3), 185-216. https://doi.org/10.1177/135910457000100301

21. Bronfenbrenner, U. (1977). Toward an experimental ecology of human development. American Psychologist, 32(7), 513-531. https://doi.org/10.1037/0003-066X.32.7.513

22. Bronfenbrenner, U., \& Morris, P. A. (2006). The bioecological model of human development. In R. M. Lerner \& W. Damon (Eds.), Handbook of child psychology: Theoretical models of human developmental (6th ed., pp. 793-828). Wiley.

23. Bryman, A. (2016). Social research methods (5th ed.). Oxford University Press. 
24. Bughio, F. A. (2013). Improving English language teaching in large classes at university level in Pakistan, unpublished doctoral dissertation, school of education, university of Sussex, UK.

25. Campbell, C. (2020). Educational equity in Canada: The case of Ontario's strategies and actions to advance excellence and equity for students. School Leadership \& Management, 1-20. https://doi.org/10.1080/13 $\underline{632434.2019 .1709165}$

26. Cancino, N., González, C., Gallardo, I., \& Estrada, C. (2016). Evaluation of a quality of life model built from data. Colombian Act of Psychology, 19(1), 310-321. https://doi.org/10.14718/ACP.2016.19.1.13

27. Centre for Public Education. (2016). Educational equity: What does it mean? How do we know when we reach it? Research Brief. Alexandria, Virginia: Author.

28. Chen, W. C. (2016). The role of grandparents in single-parent families in Taiwan. Marriage \& Family Review, 52(1), 41-63. https://doi.org/10.1080/01494929.2015.1073654

29. Christie, P. (2010). The complexity of human rights in global times: The case of the right to education in South Africa. International Journal of Educational Development, 30(1), 3-11. https://doi.org/10.1016/j.ijedud ev.2009.06.006

30. Coates, A. (2021). The prevalence of philosophical assumptions described in mixed methods research in education. Journal of Mixed Methods Research, 15(2), 171-189. https://doi.org/10.1177/1558689820958210

31. Coe, R., Waring, M., Hedges, L. V., \& Ashley, L. D. (2021). Research methods and methodologies in education. Sage.

32. Cohen, H. (2018). What is Resilience? Psych Central. Retrieved on May 5, 2021, from https://psychcentral. com/lib/what-is-resilience

33. Collaborative for Academic, Social, and Emotional Learning (2018). https://casel.org/. Accessed 12 Feb 2021.

34. Colombo, M. W. (2006). Building school partnerships with culturally and linguistically diverse families. Phi Delta Kappan, 88(4), 314-318. https://doi.org/10.1177/003172170608800414

35. Crahay, M. (2000). Can school be fair and effective? Brussels: de Boeck.

36. Creswell, J. W. (2014). Research design: Qualitative, quantitative and mixed methods approaches (2nd ed.). Sage.

37. Crawford, B. F., Snyder, K. E., \& Adelson, J. L. (2020). Exploring obstacles faced by gifted minority students through Bronfenbrenner's bioecological systems theory. High Ability Studies, 31(1), 43-74. https://doi.org /10.1080/13598139.2019.1568231

38. Cronk, B. C. (2012). How to use SPSS statistics: A step-by-step guide to analysis and interpretation. Pyrczak Publications.

39. D'Azevedo, E. F. (2015). Perception of educational equity and school climate: A case study, published doctoral dissertation, educational foundations and leaderships graduate department, George Fox University, School of Education, Newberg, Oregon.

40. Deci, E. L., \& Ryan, R. M. (2008). Hedonia, eudaimonia, and well-being: An introduction. Journal of Happiness Studies, 9(1), 1-11. https://doi.org/10.1007/s10902-006-9018-1

41. Department of Health KidsMatter. (2018). https://www.kidsmatter.edu.au/. Accessed 9 Feb 2021.

42. Deptola, A. (2021). Motivation: An integral component of resident well-being. Journal of Graduate Medical Education, 13(1), 11-14. https://doi.org/10.4300/JGME-D-20-00309.1

43. Dix, K. L., Slee, P. T., Lawson, M. J., Keeves, J. P., (2012). Implementation quality of whole-school mental health promotion and students academic performance. Child and Adolescent Mental Health, 17(1), 45-51. https://doi.org/10.1111/j.1475-3588.2011.00608.x

44. Dogra, N. (2010). Social factors that influence child mental health. In: Bhugra D, Morgan, C. (eds). Principles of social psychiatry, (2nd ed.). Wiley-Blackwell. https://doi.org/10.1002/9780470684214.ch22

45. Downie, J. M., Hay, D. A., Horner, B. J., Wichmann, H., \& Hislop, A. L. (2010). Children living with their grandparents: Resilience and wellbeing. International Journal of Social Welfare, 19(1), 8-22. https://doi.org/10. 1111/j.1468-2397.2009.00654.x

46. Echezarraga, A., Calvete, E., González-Pinto, A. M., \& Las Hayas, C. (2018). Resilience dimensions and mental health outcomes in bipolar disorder in a follow-up study. Stress and Health, 34(1), 115-126. https://doi.org/10.1002/smi.2767

47. Fearnley, B. (2020). Enhancing social work student learning: converging Bronfenbrenner, Bourdieu and practice learning. Social Work Education, 39(2), 214-226. https://doi.org/10.1080/02615479.2019.1618258

48. Fenwick-Smith, A., Dahlberg, E. E., \& Thompson, S. C. (2018). Systematic review of resilience-enhancing, universal, primary school-based mental health promotion programs. BMC Psychology, 6(1), 3-17. https://doi.org/10.1186/s40359-018-0242-3

49. Fitzpatrick, C., Conlon, A., Cleary, A., Power, M., King, F., Guerin, S. (2013). Enhancing the mental health promotion component of health and personal development programme in Irish schools. Advances in School Mental Health Promotion, 6(2), 122-138. https://doi.org/10.1080/1754730X.2013.784617

50. Foster, K., Roche, M., Delgado, C., Cuzzillo, C., Giandinoto, J. A., \& Furness, T. (2018). Resilience and mental health nursing: An integrative review of international literature. International Journal of Mental Health Nursing, 28(1), 71-85. https://doi.org/10.1111/inm.12548 
51. Fraenkel, J. R., Wallen, N. E., \& Hayun, H. H. (2012). How to design and evaluate research in education (8th ed.). McGraw-Hills.

52. Freire, C., Ferradás, M. D. M., Núñez, J. C., \& Valle, A. (2017). Factorial structure of the Ryff psychological well-being scales in university students. European Journal of Education and Psychology, 10 (1), 1-8. https://doi.org/10.1016/j.ejeps.2016.10.001

53. Fuchs, C. (2021). Social media: A critical introduction. Sage.

54. Gaias, L. M., Arnold, K. T., Liu, F. F., Pullmann, M. D., Duong, M. T., \& Lyon, A. R. (2021). Adapting strategies to promote implementation reach and equity (ASPIRE) in school mental health services. Psychology in the Schools, 1-15. https://doi.org/10.1002/pits.22515

55. Gale, T. (2011). Expansion and equity in Australian higher education: Three propositions for new relations. Discourse: Studies in the Cultural Politics of Education, 32(5), 669-685. https://doi.org/10.1 $\underline{080 / 01596306.2011 .620751}$

56. Gao, J., \& McLellan, R. (2018). Using Ryff's scales of psychological well-being in adolescents in mainland China. BMC Psychology, 6(1), 2-17. https://doi.org/10.1186/s40359-018-0231-6

57. Godinic, D., Obrenovic, B., \& Khudaykulov, A. (2020). Effects of economic uncertainty on mental health in the COVID-19 pandemic context: social identity disturbance, job uncertainty and psychological well-being model. International Journal of Innovation and Economic Development, 6, 61-74. https://doi.org/10.18775/ij ied.1849-7551-7020.2015.61.2005

58. Government of Pakistan. (2009). National Education Policy 2009. Islamabad: Ministry of Education.

59. Griffin, R. (2021). Fundamentals of management. Cengage Learning.

60. Grim, B. J. (2015). Global religious diversity: Half of the most religiously diverse countries are in Asia-Pacific region. In B. J. Grim, T. M. Johnson, V. Skirbekk, \& G. A. Zurlo (Eds.), Yearbook of international religious demography, 2,187-199. Boston: Brill. https://doi.org/10.1163/9789004297395

61. Gunin, G. B., Gravino, A., \& Bal, V. H. (2021). Advancing mental health supports for autistic postsecondary students: A call for research. Autism in Adulthood, 3(1), 30-36. https://doi.org/10.1089/aut.2020.0044

62. Halai, N. (2002). Munazza's story: Understanding science teaching and conceptions of the nature of science in Pakistan through a life history study, unpublished doctoral dissertation, University of Toronto, UK.

63. Hall, S. (2010). Supporting mental health and well-being at a whole-school level: Listening to and acting upon children's views. Emotional and Behavioural Difficulties, 15(4), 323-339. https://doi.org/10.1080/13 632752.2010 .523234

64. Hamilton, A. F., Malin, J., Hackmann, D. (2015). Racial/ethnic and gender equity patterns in Illinois high school career and technical education coursework. Journal of Career and Technical Education, 30(1), 2952. https://doi.org/10.21061/jcte.v30i1.712

65. Hao, Y. (2008). Productive activities and psychological well-being among older adults. The Journals of Gerontology Series B: Psychological Sciences and Social Sciences, 63(2), 64-72. https://doi.org/10.1093/g eronb/63.2.S64

66. Haq, S. (2015). Public policy process in Pakistan: Key causes of public policies failures. Journal of Economic and Social Thought, 2(2), 127-131.

67. Hassan, M. U. (2019). Teachers self-efficacy: Effective indicator towards students success in medium of education perspective. Problems of Education in the 21st Century, 77(5), 667-679. https://doi.org/10.332 25/pec/19.77.667

68. Hassan, M. U., \& Akbar, R. A. (2020). Tracing the effects of teachers centered teaching methods on students' achievement scores: Secondary level study. Bulletin of Education and Research, 42(1), 29-43.

69. Hassan, U. M. (2020). Effect of teachers' self-efficacy, locus of control and teaching methods on students achievement scores at secondary level in Punjab, unpublished doctoral dissertation, institute of education and research, university of the Punjab, Lahore, Pakistan.

70. Hassan, U. M., \& Akbar, R. A. (2020). Locus of control: Teachers' neglected attribute towards students' achievement scores in facing diverse socioeconomic status. Problems of Education in the 21st Century, 78(2), 282-300. https://doi.org/10.33225/pec/20.78.282

71. Hayes, N., O'Toole, L., \& Halpenny, A. M. (2017). Introducing Bronfenbrenner: A guide for practitioners and students in early years education. Routledge. https://doi.org/10.4324/9781315646206

72. Helling, J., \& Chandler, G. E. (2021). Meeting the psychological health \& growth needs of Black college students: Culture, resonance and resilience. Journal of College Student Psychotherapy, 35(2), 152-180. https://doi.org/10.1080/87568225.2019.1660291

73. Helmer, M., \& Hilhorst, D. (2006). Natural disasters and climate change. Disasters, 30, 1-4. https://doi.org/10.1 $111 / \mathrm{j} .1467-9523.2006 .00302 . \mathrm{x}$

74. Henn, C. M., Hill, C., \& Jorgensen, L. I. (2016). An investigation into the factor structure of the Ryff scales of psychological well-being. SA Journal of Industrial Psychology, 42(1), 1-12. https://doi.org/10.41 02/sajip.v42i1.1275

75. Hernández-Torrano, D., Ibrayeva, L., Sparks, J., Lim, N., Clementi, A., Almukhambetova, A., ... \& Muratkyzy, A. (2020). Mental health and well-being of university students: A bibliometric mapping of the literature. Frontiers in Psychology, 11, 1226. https://doi.org/10.3389/fpsyg.2020.01226 
76. Hillmann, J., \& Guenther, E. (2021). Organizational resilience: a valuable construct for management research? International Journal of Management Reviews, 23(1), 7-44. https://doi.org/10.1111/ijmr.12239

77. Hong, J. S., Hunter, S. C., Kim, J., Piquero, A. R., \& Narvey, C. (2021). Racial differences in the applicability of Bronfenbrenner's ecological model for adolescent bullying involvement. Deviant Behavior, 42(3), 404-424. https://doi.org/10.1080/01639625.2019.1680086

78. Houser, R. A. (2019). Counseling and educational research: Evaluation and application. Sage Publications.

79. Huppert, F. A. (2009). Psychological well-being: Evidence regarding its causes and consequences. Applied Psychology: Health and Well-Being, 1, 137-164. https://doi.org/10.1111/j.1758-0854.2009.01008.x

80. Inter-Agency Standing Committee. (2007). IASC guidelines on mental health and psychosocial support in emergency settings. Geneva: Inter-Agency Standing Committee.

81. Iqbal, H. M., Azam, S. \& Rana, R. A. (2009). Secondary school science teachers views about the 'nature of science'. Bulletin of Education and Research, 31(2), 29-44.

82. Jacob, W. J. \& Holsinger, D. B. (2008). Inequality in education: A critical analysis. In D. B. Holsinger and W. J. Jacob (Eds.), Inequality in education: Comparative and international perspectives (pp. 1-34). Hong Kong: Springer. https://doi.org/10.1007/978-90-481-2652-1_1

83. Jenkins, R., \& Barry, M. M. (2007). Implementing mental health promotion. Churchill Livingstone, Elsevier, London.

84. Johnson, R. B., \& Christensen, L. (2019). Educational research: Quantitative, qualitative, and mixed approaches. Sage publications.

85. Joshanloo, M., \& Nosratabadi, M. (2009). Levels of mental health continuum and personality traits. Social Indicators Research, 90(2), 211-224. https://doi.org/10.1007/s11205-008-9253-4

86. Kaufman, S. B. (2021). Transcend the new science of self-actualization. Penguin.

87. Kessler, R. C., Berglund, P., Demler, O., Jin, R., Merikangas, K. R., \& Walters, E. E. (2005). Lifetime prevalence and age-of-onset distributions of DSM-IV disorders in the National Comorbidity Survey Replication. Archives of General Psychiatry, 62(6), 593-602. https://doi.org/10.1001/archpsyc.62.6.593

88. Keyes, C. L. M. (2002). The mental health continuum: From languishing to flourishing in life. Journal of Health and Social Research, 43(2), 207-222. https://doi.org/10.2307/3090197

89. Khumalo, I. P., Temane, Q. M., \& Wissing, M. P. (2012). Socio-demographic variables, general psychological well-being and the mental health continuum in an African context. Social Indicators Research, 105(3), 419-442. https://doi.org/10.1007/s11205-010-9777-2

90. Kieling, C., Baker-Henningham, H., Belfer, M., Conti, G., Ertem, I., Omigbodun, O., Rohde, L. A., Srinath, S., Ulkuer, N., Rahman, A. (2011). Child and adolescent mental health worldwide: Evidence for action, The Lancet, 378(9801), 1515-1525. https://doi.org/10.1016/S0140-6736(11)60827-1

91. Kim, E. H., Flack, C. B., Parham, K., \& Wohlstetter, P. (2021). Equity in Secondary Career and Technical Education in the United States: A theoretical framework and systematic literature review. Review of Educational Research, 91(3), 356-396. https://doi.org/10.3102/0034654321995243

92. Kimber, B., Sandell, R., \& Bremberg, S. (2008). Social and emotional training in Swedish schools for the promotion of mental health: An effectiveness study of 5 years of intervention. Health Education Research, 23(6), 931-940. https://doi.org/10.1093/her/cyn040

93. Krass, P., \& Doupnik, S. K. (2021). Equity in emergency mental health care. pediatrics, 147(5). e2020049843. https://doi.org/10.1542/peds.2020-049843

94. Latief, N. S. A., Retnowati E. (2019). Loneliness and self esteem as predictor of internet addiction in adolescents, in 3rd International Conference on Current Issues in Education, Yogyakarta: Atlantis Press. https://doi.org/10.2991/iccie-18.2019.65

95. Latipun, L., Amalia, D. R., \& Hasanati, N. (2019). Relation social support and psychological well-being among schizophrenic patients: self-care as mediation variable? 4th ASEAN Conference on Psychology, Counselling, and Humanities, Malang: Atlantis Press. https://doi.org/10.2991/acpch-18.2019.1

96. Lee, T., S. H., Sun, H. F., \& Chiang, H. H. (2019). Development and validation of the short-form Ryff's psychological well-being scale for clinical nurses in Taiwan. Journal of Medical Sciences, 39(4), 157-162. https://doi.org/10.4103/jmedsci.jmedsci_191_18

97. Lin, K. L. (2016). Resilience narrative of a Taiwanese preschool boy with Asperger's syndrome: The lens of bioecological model. Research Journal of Social Sciences, 9(1), 15-22. https://doi.org/10.1080/1 0665684.2016.1250237

98. Liou, D. D., Marsh, T. E., \& Antrop-González, R. (2017). Urban sanctuary schools for diverse populations: Examining curricular expectations and school effectiveness for student learning. Equity and Excellence in Education, 50(1), 68-83.

99. Liu, J. J., Reed, M., \& Girard, T. A. (2017). Advancing resilience: An integrative, multi-system model of resilience. Personality and Individual Differences, 111, 111-118. https://doi.org/10.1016/j.paid.2017.02.007

100.Loera-Malvaez N., Balcázar Nava P., Trejo-González, L., Gurrola-Peña G. M. \& Bonilla-Muñoz P. (2017). Adaptation of the Ryff psychological well-being scale in pre-university adolescents. Neurology, Neurosurgery and Psychiatry, 41(3), 90-97. 
101.Lopez, M. E. (2003). Transforming schools through community organizing: A research review. Cambridge, MA: Harvard family education research project, Harvard graduate school of education.

102.Lukat, J., Margraf, J., Lutz, R., van der Veld, W. M., Becker, E. S. (2016). Psychometric properties of the Positive Mental Health Scale (PMH-scale). BMC Psychology, 4(8), 2-14. https://doi.org/10.1186/s40359-0160111-X

103.Lunenburg, F. C., \& Ornstein, A. (2021). Educational administration: Concepts and practices. SAGE Publications.

104.Mafud, J. L. C. (2016). Socialization and organizational commitment: a review based on labor wellbeing. Teaching and Research in Psychology, 21(3), 239-247.

105.Mahmood, N. (2013). Institutional review of Punjab examination commission (PEC) and Punjab Education Assessment System (PEAS). Cambridge: Cambridge Education.

106. Mahmood, T., \& Gondal, M. B. (2017). Effect of school environment on students' achievement: Cross comparison of Urdu and English medium classes in Punjab province. Pakistan Journal of Education, 34(1), 6780. https://doi.org/10.30971/pje.v34i1.191

107. Maiztegui-Oñate, C., \& Santibáñez-Gruber, R. (2008). Access to education and equity in plural societies. Intercultural Education, 19(5), 373-381. https://doi.org/10.1080/14675980802531432

108.Manan, S. A., Channa, L. A., David, M. K., \& Amin, M. (2021). Negotiating English-only gatekeepers: Teachers' agency through a public sphere lens. Current Issues in Language Planning, 22(3), 290-307. https://doi.org/10.1080/14664208.2020.1839219

109. Manyena, S. B. (2006). The concept of resilience revisited. Disasters, 30, 434-450. https://doi.org/10.111 1/j.0361-3666.2006.00331.x

110.Margrain, V., \& Hultman, A. L. (2019). Challenging democracy in early childhood education: Engagement in changing global contexts, 28, Springer. https://doi.org/10.1007/978-981-13-7771-6

111.Martin, J., \& Oswin, F. (2010). Mental health, access, and equity in higher education. Advances in Social Work, 11(1), 48-66. https://doi.org/10.18060/240

112.Martin, L., Dixon, C., \& Betser, S. (2018). Iterative design toward equity: Youth repertoires of practice in a high school maker space. Equity and Excellence in Education, 51(1), 36-47. https://doi.org/10.108 $\underline{0 / 10665684.2018 .1436997}$

113. Masten, A. S. (2014). Global perspectives on resilience in children and youth. Child Development, 85(1), 6-20. https://doi.org/10.1111/cdev.12205

114. Masten, A., \& Narayan, A. J. (2012). Child development in the context of disaster, war, and terrorism: Pathways of risk and resilience. Annual Review of Psychology, 63, 227-257. https://doi.org/10.1146/annurevpsych-120710-100356

115.McAdams, D. P., \& McLean, K. C. (2013). Narrative identity. Current Directions in Psychological Science, 22(3), 233-238. https://doi.org/10.1177/0963721413475622

116.McKenney, S., \& Reeves, T. C. (2021). Educational design research: Portraying, conducting, and enhancing productive scholarship. Medical Education, 55(1), 82-92. https://doi.org/10.1111/medu.14280

117.Mediratta, K., Shah, S., \& McAlister, S. (2009). Community organizing for stronger schools: Strategies and successes. Harvard Education Press.

118. Mertler, C. A. (2021). Introduction to educational research. Sage publications.

119.Millán, A., Calvanese, N., \& D'Aubeterre, M. E. (2017). Working conditions, work stress, university dependency and psychological well-being in university teachers. REDU. Journal of University Teaching, 15(1), 195-218. https://doi.org/10.4995/redu.2017.6009

120.Nguyen, N. (2021). Rethinking activist educational research: definitions, methodologies, and ethics. Critical Studies in Education, 62(2), 258-273. https://doi.org/10.1080/17508487.2019.1630458

121.Nygreen, K. (2016). Competing paradigms of educational justice: Parent organizing for educational equity in a Neoliberal reform context, Equity and Excellence in Education, 49(2), 202-214. https://doi.org/10.1080/1 $\underline{0665684.2016 .1144832}$

122.O'Reilly, M., Svirydzenka, N., Adams, S., \& Dogra, N. (2018). Review of mental health promotion interventions in schools. Social Psychiatry and Psychiatric Epidemiology, 53(7), 647-662. https://doi.org/10. 1007/s00127-018-1530-1

123.OECD. (2001). Education policy analysis. Paris: OECD. https://doi.org/10.1787/epa-2001-en

124.Otu, A., Charles, C. H., \& Yaya, S. (2020). Mental health and psychosocial well-being during the COVID-19 pandemic: The invisible elephant in the room. International Journal of Mental Health Systems, 14, 1-5. https://doi.org/10.1186/s13033-020-00371-w

125.Páez-Gallego, J., Gallardo-López, J. A., López-Noguero, F., \& Rodrigo-Moriche, M. P. (2020). Analysis of the relationship between psychological well-being and decision making in adolescent students. Frontiers in Psychology, 11, 1195. https://doi.org/10.3389/fpsyg.2020.01195

126.Pakistan Education Statistics. (2018). National education management information system academy of educational planning and management, Ministry of federal education and professional training, Government of Pakistan, Islamabad. 
127.Panopoulos, N., \& Drossinou-Korea, M. (2020). Bronfenbrenner's theory and teaching intervention: The case of a student with intellectual disability. Journal of Language and Linguistic Studies, 16(2), 537-551. https://doi.org/10.17263/j1ls.759243

128.Pantuliano, S., \& Pavanello, S. (2009). Taking drought into account: Addressing chronic vulnerability among pastoralists in the Horn of Africa. Humanitarian policy group policy, overseas development institute.

129.Pardeller, S., Kemmler, G., Hoertnagl, C. M., \& Hofer, A. (2020). Associations between resilience and quality of life in patients experiencing a depressive episode. Psychiatry Research, 292, 113353. https://doi.org/10.10 16/i.psychres.2020.113353

130.PeConga, E. K., Gauthier, G. M., Holloway, A., Walker, R. S. W., Rosencrans, P. L., Zoellner, L. A., \& Bedard-Gilligan, M. (2020). Resilience is spreading: Mental health within the COVID-19 pandemic. Psychological Trauma: Theory, Research, Practice, and Policy, 12(1), 47-48. https://doi.org/10 $.1037 / \mathrm{tra0000874}$

131.Plevyak, L. H. (2003). Parent involvement in education: Who decides? The Education Digest, 69(2), 32-38.

132.Poloni, N., Zizolfi, D., Ielmini, M., Pagani, R., Caselli, I., Diurni, M., ... \& Callegari, C. (2018). A naturalistic study on the relationship among resilient factors, psychiatric symptoms, and psychosocial functioning in a sample of residential patients with psychosis. Psychology Research and Behavior Management, 11, 123-131. https://doi.org/10.2147/PRBM.S159571

133. Popescu, G. H. (2016). The effect of mandatory prolonged detention on the mental health of asylum seekers and refugees. American Journal of Medical Research, 3(2), 188-194. https://doi.org/10.22381/AJMR3220169

134.Pressman, S. D., Jenkins, B. N., \& Moskowitz, J. T. (2019). Positive affect and health: What do we know and where next should we go? Annual Review of Psychology, 70, 627-650. https://doi.org/10.1146/annurev-psych010418-102955

135.Prime, H., Wade, M., \& Browne, D. T. (2020). Risk and resilience in family well-being during the COVID-19 pandemic. American Psychologist, 75(5), 631-643. https://doi.org/10.1037/amp0000660

136.Prince-Embury, S. (2013). The Resiliency scales for children and adolescents: theory, research, and clinical application, In Resilience in Children, Adolescents and Adults, eds S. Prince-Embury and D. H. Saklofske (New York, NY: Springer), 19-44. https://doi.org/10.1007/978-1-4614-4939-3 3

137.Prince-Embury, S., \& Courville, T. (2008). Comparison of one-, two-, and three-factor models of personal resiliency using the resiliency scales for children and adolescents. Canadian Journal of School Psychology, 23(1), 11-25. https://doi.org/10.1177/0829573508316589

138.Public Health England (2015). Promoting children and young people's emotional health and well-being: a whole school and college approach. Public Health England, London. https://www.gov.uk/gover nment/publi cations/promoting-children-and-young-peoples-emotional-health-and-well-being, Accessed 12 Feb 2021.

139.Punjab Development Statistics. (2015). Bureau of statistics, Government of the Punjab. Lahore: Pakistan.

140.Puroila, A.-M., \& Estola, E. (2014). Not babies anymore: Young children's narrative identities in finnish day care centers. International Journal of Early Childhood, 46(2), 187-203. https://doi.org/10.1007/s13158-0130096-z

141.Radhakrishna, R. B. (2007). Tips for developing and testing questionnaires/instruments. Journal of Extension, 45(1), 1-4.

142.Rehman, H., \& Khan N., (2011). The flaws in Pakistan's education system. Abasyn Journal of Social Sciences, $4(1), 70-83$.

143.Reyes, J. A., Elias, M. J., Parker, S. J., \& Rosenblatt, J. L. (2013). Promoting educational equity in disadvantaged youth: The role of resilience and social-emotional learning. In Handbook of resilience in children (pp. 349-370). Springer, Boston, MA. https://doi.org/10.1007/978-1-4614-3661-4_20

144.Riordan, M., Klein, E. J., \& Gaynor, C. (2019). Teaching for equity and deeper learning: How does professional learning transfer to teachers' practice and influence students' experiences? Equity and Excellence in Education, 52(3), 327-345. https://doi.org/10.1080/10665684.2019.1647808

145.Rosa-Rodríguez, Y., Cartagena, N. N., Peña, Y. M., Berrios, A. Q., \& Osorio, N. T. (2015). Dimensions of psychological well-being and perceived social support in relation to sex and level of study in university students. Advances in Latin American Psychology, 33(1), 31-43. https://doi.org/10.12804/apl33.01.2015.03

146. Rothi, D., Leavey, G., Best, R. (2008). On the front-line: Teachers as active observers of pupils mental health. Teaching and Teacher Education, 24(5), 1217-1231. https://doi.org/10.1016/j.tate.2007.09.011

147.Rowling, L. (2009). Strengthening school' in school mental health promotion. Health Education, 109(4), 357368. https://doi.org/10.1108/09654280910970929

148.Ryan, R. M., \& Deci, E. L. (2001). On happiness and human potentials: A review of research on hedonic and eudaimonic well-being. Annual Review of Psychology,52(1), 141-166. https://doi.org/10.1146/annur ev.psych.52.1.141

149.Ryff, C. D. (1989). Happiness is everything, or is it? Explorations on the meaning of psychological wellbeing. Journal of Personality and Social Psychology, 57(6), 1069. https://doi.org/10.1037/0022-3514.57.6.1069

150.Ryff, C. D. (2014). Psychological well-being revisited: Advances in the science and practice of eudaimonia. Psychotherapy and Psychosomatics, 83(1), 10-28. https://doi.org/10.1159/000353263 
151.Ryff, C., \& Keyes, C. (1995). The structure of psychological well-being revisited. Journal of Personality and Social Psychology, 69(4), 719-727. https://doi.org/10.1037//0022-3514.69.4.719

152.Saldaña, J. (2021). The coding manual for qualitative researchers. Sage.

153.Samani, S., Jokar, B., \& Sahragard, N. (2007). Effects of resilience on mental health and life satisfaction. Iranian Journal of Psychiatry and Clinical Psychology, 13(3), 290-295.

154.Sarafraz, M. R., Chavoshi H., Alinaghi M. (2019). Social networks and students: educational performance, psychological well-being, and mental health. International Journal of School Health, 6(3), 1-6. https://doi.org/10.5812/intjsh.82609

155.Satici, S. A. (2016). Psychological vulnerability, resilience, and subjective well-being: The mediating role of hope. Personality and Individual Differences, 102, 68-73. https://doi.org/10.1016/j.paid.2016.06.057

156.Schäfer, J. Ö., Naumann, E., Holmes, E. A., Tuschen-Caffier, B., \& Samson, A. C. (2017). Emotion regulation strategies in depressive and anxiety symptoms in youth: a meta-analytic review. Journal of Youth and Adolescence, 46(2), 261-276. https://doi.org/10.1007/s10964-016-0585-0

157.Scott, B. (2006). Six goals of educational equity and school reform, Intercultural development research association South central collaborative for Equity, San Antonio, Taxas. https://www.idra.org/equity-assistancecenter/six-goals-of-education-equity/

158.Serneels, P., Beegle, K., \& Dillon, A. (2017). Do returns to education depend on how and whom you ask? Economics of Education Review, 60, 5-19. https://doi.org/10.1016/j.econedurev.2017.07.010

159. Shamsitdinova, M. (2021). Difficulties in teaching law students listening comprehension in English language teaching. The American Journal of Political Science Law and Criminology, 3(1), 1-8.

160.Smith, L. T. (2021). Decolonizing methodologies: Research and indigenous peoples. Zed Books Ltd.

161.Social and Emotional Aspects of Learning (2010). Programme in secondary schools: National evaluation. Department for children, schools and families, Nottingham.

162.Soto, J. P, \& Almagiá, E. B (2017). Work-family conflict and psychological well-being in workers of industrial companies in Chile. Peruvian Journal of Psychology and Social Work, 4(1), 15-24.

163. State of Education Survey Report (2017). Rising to the challenge: examining the pressures of schools and how they are responding. https://thekeysupport.com/wp-content/uploads/2018/03/state-of-education-report-2015.pdf

164. Stockemer, D. (2019). Quantitative methods for the social sciences a practical introduction with examples in SPSS and Stata, Gewerbestrasse: Switzerland, Springer. https://doi.org/10.1007/978-3-319-99118-4

165.Taj, T. (2019). Impact of medium of instruction on student's learning. International Journal of Research in Social Sciences, 9(4), 741-753.

166.Takyi, S. A., Amponsah, O., Asibey, M. O., \& Ayambire, R. A. (2021). An overview of Ghana's educational system and its implication for educational equity. International Journal of Leadership in Education, 24(2), 157182. https://doi.org/10.1080/13603124.2019.1613565

167.Tamura, S., Suzuki, K., Ito, Y., \& Fukawa, A. (2021). Factors related to the resilience and mental health of adult cancer patients: a systematic review. Supportive Care in Cancer, 1-16. https://doi.org/10.1007/s00520020-05943-7

168. Thomas, G. (2021). How to do your case study. Sage.

169.Tomyn, A. J., \& Weinberg, M. K. (2018). Resilience and subjective wellbeing: A psychometric evaluation in young Australian adults. Australian Psychologist, 53(1), 68-76. https://doi.org/10.1111/ap.12251

170.Trevino, L. K., \& Nelson, K. A. (2021). Managing business ethics: Straight talk about how to do it right. John Wiley \& Sons.

171.Trinidad, J. E. (2021). Equity, engagement, and health: school organisational issues and priorities during COVID-19. Journal of Educational Administration and History, 53(1), 67-80. https://doi.org/10.1080/002 20620.2020 .1858764

172.Trumpf, J., Becker, E. S., Vriends, N., Meyer, A. H., \& Margraf, J. (2009). Rates and predictors of remission in young women with specific phobia: A prospective community study. Journal of Anxiety Disorders, 23(7), 958964. https://doi.org/10.1016/j.janxdis.2009.06.005

173.Trumpf, J., Vriends, N., Meyer, A. H., Becker, E. S., Neumer, S. P., \& Margraf, J. (2010). The Dresden predictor study of anxiety and depression: objectives, design, and methods. Social Psychiatry and Psychiatric Epidemiology, 45(9), 853-864. https://doi.org/10.1007/s00127-009-0133-2

174.UNESCO. (2017). A guide for ensuring inclusion and equity in education. Paris: UNESCO.

175.Ungar, M. (2012). The social ecology of resilience: A handbook of theory and practice. Springer.

176.Ungar, M., \& Theron, L. (2020). Resilience and mental health: How multisystemic processes contribute to positive outcomes. The Lancet Psychiatry, 7(5), 441-448. https://doi.org/10.1016/S2215-0366(19)30434-1

177.UNICEF. (2010). Re-focusing on equity: Questions and answers. Author.

178.Van de Vijver, F. J. (2021). Methods and data analysis for cross-cultural research. Cambridge University Press.

179.van Griethuijsen, R. A. L. F., van Eijck, M. W., Haste, H., den Brok, P. J., Skinner, N. C., Mansour, N., Gencer, A. S., BouJaoude, S. B. (2015). Global patterns in students' views of science and interest in science. Research in Science Education, 45(4), 581-603. https://doi.org/10.1007/s11165-014-9438-6 
180.VanderWeele, T. J., Chen, Y., Long, K., Kim, E. S., Trudel-Fitzgerald, C., Kubzanksy, L. D. (2020). Positive Epidemiology? in press, 31(2), 189-193. https://doi.org/10.1097/EDE.0000000000001147

181.Verdolini, N., Amoretti, S., Montejo, L., García-Rizo, C., Hogg, B., Mezquida, G., ... \& Solé, B. (2021). Resilience and mental health during the COVID-19 pandemic. Journal of Affective Disorders, 283, 156-164. https://doi.org/10.1016/j.jad.2021.01.055

182.Vila, L. E. (2000). The non-monetary benefits of education. European Journal of Education, 35(1), 21-32. https://doi.org/10.1111/1467-3435.00003

183. Villegas, A. M., \& Lucas, T. (2002). Preparing culturally responsive teachers: Rethinking the curriculum. Journal of Teacher Education, 53(1), 20-32. https://doi.org/10.1177/0022487102053001003

184.Vriends, N., Becker, E. S., Meyer, A., Williams, S. L., Lutz, R., \& Margraf, J. (2007). Recovery from social phobia in the community and its predictors: data from a longitudinal epidemiological study. Journal of anxiety disorders, 21(3), 320-337. https://doi.org/10.1016/j.janxdis.2006.06.005

185.Walsh, F. (2016). Family resilience: A developmental systems framework. European Journal of Developmental Psychology, 13(3), 313-324. https://doi.org/10.1080/17405629.2016.1154035

186.Warren, M. (2014). Transforming public education: The need for an educational justice movement. New England Journal of Public Policy, 26(1), 1-16.

187.Warren, M., \& Mapp, K. (2011). A match on dry grass: Community organizing as a catalyst for school reform. Oxford University Press.

188. Weare, K., \& Nind, M. (2011). Mental health promotion and problem prevention in schools: what does the evidence say? Health Promotion International, 26(1), 29-69. https://doi.org/10.1093/heapro/dar075

189.Weich, S., Brugha, T., King, M., McManus, S., Beddington, P., Jenkins, R., Cooper, C., McBride, O., \& Stewart-Brown, S. (2011). Mental well-being and mental illness: Findings from the adult psychiatric morbidity survey for England 2007. The British Journal of Psychiatry, 199, 23-28. https://doi.org/10.1192/b jp.bp. 111.091496

190.Weist, M. D., Murray, M. (2008). Advancing school mental health promotion globally. Advances in School Mental Health Promotion, 1(1), 2-12. https://doi.org/10.1080/1754730X.2008.9715740

191.Weiten, W. (2021). Psychology: Themes and variations. Cengage Learning.

192.West, A. (2006). School choice, equity and social justice: the case for more control. British Journal of Educational Studies, 54(1), 15-33. https://doi.org/10.1111/j.1467-8527.2006.00334.X

193.Westerhof, G. J., \& Keyes, C. L. M. (2010). Mental illness and mental health: The two continua model across the lifespan. Journal of Adult Development, 17(2), 110-119. https://doi.org/10.1007/s10804-009-9082-y

194.Wilson-Strydom, M., \& Okkolin, M. A. (2016). Enabling environments for equity, access and quality education post-2015: Lessons from South Africa and Tanzania. International Journal of Educational Development, 49, 225-233. https://doi.org/10.1016/j.ijedudev.2016.03.010

195.Winefield, H. R., Gill, T. K., Taylor, A. W., \& Pilkington, R. M. (2012). Psychological well-being and psychological distress: is it necessary to measure both? Psychology of Well-Being: Theory, Research and Practice, 2(1), 2-14. https://doi.org/10.1186/2211-1522-2-3

196.Willems, J. (2010). The equity raw-score matrix: a multi-dimensional indicator of potential disadvantage in higher education. Higher Education Research \& Development, 29(6), 603-621. https://doi.org/10.1080/07 294361003592058

197.Willingham, D. T. (2021). Why don't students like school? A cognitive scientist answers questions about how the mind works and what it means for the classroom. John Wiley \& Sons.

198. World Health Organisation (2016). Mental health: strengthening our response. http://www.who.int/mediacentr e/factsheets/fs220/en/, Accessed 1 June 2020.

199. World Health Organization. (2005). Promoting mental health: Concepts, emerging evidence, practice. Geneva: WHO.

200.Wu, Y., Sang, Z. Q., Zhang, X. C., \& Margraf, J. (2020). The relationship between resilience and mental health in Chinese college students: a longitudinal cross-lagged analysis. Frontiers in Psychology, 11, 108. https://doi.org/10.3389/fpsyg. 2020.00108

201.Xu, J., \& Roberts, R. E. (2010). The power of positive emotions: It's a matter of life or death-Subjective wellbeing and longevity over 28 years in a general population. Health Psychology, 29, 9-19. https://doi.org/10 $.1037 / \mathrm{a} 0016767$

202.Zina, O. (2021). The essential guide to doing your research project. Sage.

203.Zouwen, J. V. D. (2000). An assessment of the difficulty of questions used in the ISSP-questionnaires, the clarity of their wording, and the comparability of the responses. Central Archive for Empirical Social Research, 46, 96-114. https://nbn-resolving.org/urn:nbn:de:0168-ssoar-199369 